\title{
Municipal Jerusalem in the Age of Urban Democracy: On the Difference between What Happened and What Is Said to Have Happened
}

\author{
Jens Hanssen
}

There is a secret agreement between past generations and the present one. Then our coming was expected on earth. Then, like every generation that preceded us, we have been endowed with a weak Messianic power, a power to which the past has a claim.

WALTER BENJAMIN

History means both the facts of the matter and a narrative of those facts. MICHEL-ROLPH TROUILLOT

What is the relationship between the act of writing urban history and historical processes themselves? How can Jerusalemites, Beirutis, or Baghdadis reclaim their urban pasts when their archives have been confiscated by occupation forces, destroyed by civil war and looted during European, American, and Israeli occupations? ${ }^{1}$ Can the urban fabric of Aleppo and other Syrian towns, bombed to smithereens by the Syrian government over the past seven years, be rebuilt without the institutional memory of their municipalities? What role might urban history play in national reconciliation once the twin tyrannies of

1 Gish Amit, "Salvage or Plunder: Israel's 'Collection' of Private Palestinian Libraries in West Jerusalem," Journal of Palestine Studies 40, no. 4 (2011); Nadya Sbaiti and Sara Scalenghe, "Conducting Research in Lebanon: an Overview of Historical Sources in Beirut (Part I)," Middle East Studies Association Bulletin 37, no. 1 (2003); Hala Fattah et al., "Opening the Doors: Intellectual Life and Academic Conditions in Post-War Baghdad," The Iraqi Observatory, July 15, 2003, accessed January 1, 2018, https://www.h-net.org/about/press/opening_doors/.

(C) JENS HANSSEN, 2018 | DOI:10.1163/9789004375741_017

This is an open access chapter distributed under the terms of the prevailing CC-BY-NC-ND License at the time of publication. 
Assadist and IsIs rule have ended? Can Palestinian and Israeli cities become models of coexistence after the structures of occupation and Zionist supremacy are dismantled, or will they turn into war zones?

Historians do well to stay away from guessing the future, but we cannot afford either to omit our own present-past or Arab Jerusalem's past-futures. As Paul Ricoeur reminds us, "the unfulfilled future of the past forms perhaps the richest part of tradition." ${ }^{2}$ With the publication of this book, its editors have moved their magnificent three-stage project from the logistical and methodological rescue operations of locating archives and inventorizing their contents to the "historiographical operation" of revision and recontextualization of Jerusalem's history between 1840 and $1940 .^{3}$

In the second part of this chapter, I offer my version of Jerusalem's recontextualization by arguing that, along with other Arab provincial municipalities in the late Ottoman empire, the capital of Palestine was a site of urban experiments in democracy. Though Arab municipalities have been disempowered since World War I, recalling the forgotten promise of this history today - with Benjamin - "carries a hidden inventory by which it points to redemption." First, however, we need to consider what historical forces have kept this promise unfulfilled and how the Open Jerusalem project relates to these forces.

\section{Unsilencing the Past: "Open Jerusalem" Meets "Teaching the Palestinian Revolution"}

When at the height of the anticolonial struggle, Frantz Fanon declared that "for the colonized subject, objectivity is always used against him," he could not have foreseen the extent to which in late settler colonialism, the denial of objectivity, too, is working against the colonized subject. ${ }^{4}$ In Silencing the Past, Michel-Rolph Trouillot offers a powerful critique of how the academic writing of history has tried to complete what the French, British, Spanish, and American armies have been working unsuccessfully to defeat; namely the

2 Paul Ricoeur, "Identité narrative et communauté historique," Cahier de Politique Autrement (October 1994).

3 The term "historiographical operation" is a gesture toward Michel de Certeau's, The Writing of History, trans. Tom Conley (New York: Columbia University Press, 1988).

4 Frantz Fanon, The Wretched of the Earth, trans. Richard Philcox (1961; repr. New York: Grove Press, 2005), 37. 
Haitian Revolution. ${ }^{5}$ The problem, Trouillot insists, is not simply archival but rather the historiographical denial of the very possibility of Haiti's independence struggle.

Silencing does not imply the inability to speak but rather the suppression of both the act of speech and its effects and afterlives. Thus, on its own, the reconstruction of the late Ottoman municipal horizon I offer in the second part of this chapter does not suffice. As David Scott reminds us, the contextualist methods of new historicism - not unlike the old historicism that Benjamin dissected in On the Concept of History - have failed to look beyond the past's horizons. Content in the wisdom that what happened is not exactly what is said to have happened, such historians leave the field of interpretation to the victors of history. Even someone of the caliber of Quentin Skinner, according to Scott, "having discharged his duty of reconstructing the past, bows and exits just at the point at which the question arises of determining and judging the stakes in the present of the rehistoricizing intervention." ${ }^{\prime 6}$

What is important to note for the three-stage Open Jerusalem project is that this silencing occurs at four moments in the process of historical production: when actors enter the historical record (silences in creation of fact); when historical facts are assembled (silences produced by the archive); when data is retrieved (silences produced in historical narratives); and finally the silences produced by particular theoretical choices. ${ }^{7}$ In "Permission to Narrate," a famous critique of Noam Chomsky's The Fateful Triangle which in some ways anticipated Trouillot's third moment of silencing, Edward Said concluded that anti-imperial criticism of Israel and us Middle East policy is one thing, and writing the Palestinian struggle into history quite another. ${ }^{8}$ Since the end of the Cold War, as Joseph Massad and others have argued, some postcolonial theorists' disavowal of postcolonial studies' radical, third-world roots has

5 Michel-Rolph Trouillot, Silencing the Past: Power and the Production of History (Boston: Beacon Press, 1995). For a recent expansion of this indictment of Haitian historiography of the complicity of the Western literary canon and Caribbean theorizing in the denial of indigenous genocide survival, see Melanie Newton, "The Race Leapt at Sauteurs: Genocide, Narrative and Indigenous Exile from the Caribbean Archipelago," Caribbean Quarterly 6o, no. 2 (2014).

6 David Scott, Conscripts of Modernity: The Tragedy of Colonial Enlightenment (Durham: Duke University Press, 2004), 54.

7 Trouillot, Silencing the Past, 26. For a comprehensive overview of both the silences and the pitfalls of unsilencing Palestinian history, see Beshara B. Doumani, "Rediscovering Ottoman Palestine: Writing Palestinians into History," Journal of Palestine Studies 21, no. 2 (1992).

8 Edward Said, "Permission to Narrate," Journal of Palestine Studies 13, no. 3 (1984). 
perpetuated the long-standing empirical silencing of Palestinians. ${ }^{9}$ Trouillot's fourth moment of theoretical silencing is therefore something the Open Jerusalem project has to reckon with as much as with the modes of fact archive - and narrative assemblage. The task at hand is to produce historical theory and method out of the Palestinian experience.

If Haiti has been punished for achieving independence in 1804 against all the brutal odds of history and historiography, and if these odds still punish Palestine for the defeat of 1948, "a touch of perversity" inhabits both forms of vituperation. ${ }^{10}$ To channel Trouillot, the more Zionist settlers and mercenaries conquered and displaced Palestinian men and women, the more the West wrote and talked about Judeo-Christian civilization. Indeed, Trouillot's reading of Haiti readily applies to the Palestinian revolution's impossibility: the practice of expulsion "invented, then perpetuated the [Palestinians'] position at the bottom of the human world."11 The contradiction is that the Israeli catalogue of structural violence and physical erasure - from the Law of Return in 1950 to the recent criminalization of Nakba commemorations - evinces an acute anxiety that Palestinian historicity, that is, the fact of being in and of history, unsettles the triumphant self-perception that what happened is what must have happened.

The only historian who is capable of fanning the spark of hope in the past is the one who is convinced that even the dead will not be safe from the enemy [even] if ... he has never ceased to be victorious. ${ }^{12}$

At this juncture, it is important to insist that even after 1948, Palestinians were agents, actors, and subjects of history and not just refugees, the only analytical category that has elicited global empathy and allowed them to enter the all-too

Joseph Massad, “The 'Post-colonial' Colony: Time, Space and Bodies in Palestine/Israel," in The Pre-occupation of Postcolonial Studies, ed. Fawzia Afzal-Khan and Kalpana SeshadriCrooks (Durham: Duke University Press, 200o); Massad, "Affiliating with Edward Said," in Edward Said: A Legacy of Emancipation and Representation, ed. Adel Iskander and Hakem Rustom (Berkeley: University of California Press, 2010). For a trenchant critique of postcolonial studies' culturalist turn in general and the battle over Edward Said's legacy in particular, see Neil Lazarus, The Postcolonial Unconscious (Cambridge: Cambridge University Press, 2011), esp. 183-203. Meanwhile, Zionist scholars worry about the continued theoretical threat of postcolonialism to Israel: Donna Robinson Divine and Philip Carl Salzman, eds., Postcolonial Theory and the Arab-Israel Conflict (London: Routledge, 2008).

10 Trouillot, Silencing the Past, 75.

11 Ibid., 77.

12 Benjamin, "Thesis VI," On the Concept of History. 
dominant Arab-Israeli conflict literature. A different pedagogical approach to tap into Palestinians' hidden inventories of history has just been launched by Oxford University. ${ }^{13}$ The Palestinian Revolution website offers an array of English and Arabic documents, memoires, interviews, and other teaching materials from the Nakba to the Israeli siege of Beirut in 1982. Focusing on the history of little-known revolutionary cadres, the project brings to life the local, regional, and internationalist dimensions of liberation struggle during these years. Karma Nabulsi's and Abdel Razzaq Takriti's "Teaching the Palestinian Revolution" offers a productive counterpoint for Open Jerusalem, and its pedagogy merits exposition to conclude this section:

Today, Palestinian history is predominantly taught at most Arab institutions under the heading of "the Palestinian Cause," al-Qadiya al-Filastinya, while in Europe and the United States it generally features under "ArabIsraeli Conflict" courses. Around these syllabi, dozens of textbooks, readers, and documentary source collections have been developed. As much as they provide valuable teaching material, they also restrict what can be taught and learnt, and especially what can be understood; their emphasis is on top-down state, diplomatic and military themes in history and politics, as well as overarching economic and social superstructures. In these perspectives, the Palestinian people are generally seen as objects of politics and history. Teaching the Palestinian revolution opens up different possibilities ... While taking account of the role of external historical forces, the focus here is entirely on the Palestinians themselves: their popular structures, movements, cadres, philosophies, songs, poetry, art, tactics, and strategies, rather than policies and designs drawn up by others.

The testimonies of dozens of cadres of the Palestinian revolution raise what Scott called "the stakes in the present of the rehistoricizing intervention." Against this backdrop, let me turn to recontextualizing Jerusalem in the late Ottoman family of municipalities.

13 Website of The Palestinian Revolution, accessed January 17, 2018, http://learnpalestine .politics.ox.ac.uk/. 


\section{Ottoman Municipalities in the Arab Provinces}

I have borrowed the concept of urban democracy in my title from the historian Donald Read. ${ }^{14}$ Social historians and discourse analysts of Europe and its colonies have demonstrated how demophobia - fear of crowds - was expressed in myriads of late-nineteenth century literary texts and archival documents; and how it shaped modern governmentality. ${ }^{15}$ In contrast, Read's Age of Urban Democracy shows how the exponential population growth in late Victorian England led to the rise of mass participation in the political process. His argument helps us to understand how political culture came to be structured not only by the menace of mass mobilization or the fear of grassroots change writ large, the totalitarian aftermath after World War I, and the increasingly coercive practices of the liberal state after World War II notwithstanding. The emergence of "municipal socialism" in France that William Cohen observed in fin-de-siècle Lyon, in particular, presents an example of the promises of electoral street campaigns and the improvement of life in cities under enormous demographic pressure. ${ }^{16}$

I have begun this section with these general remarks in order to challenge the tendency to write victors' history when judging hopeful beginnings such as the admittedly rocky history of Ottoman municipalities by the subsequent events of colonial occupation. Lamenting the "enormous condescension of posteriority" as did E. P. Thompson is not a license "to blot out everything [we] know about the later course of history."17 Nor would Benjamin want the "secret agreement" of generations to be governed by nostalgia for a golden age irretrievably lost to the overpowering forces of capitalist modernity.

Ottoman municipalities that cropped up all across the Arab provinces - first in Tunis (1858) and Beirut (1861), then Jerusalem (1863), Tripoli, Libya (1867), Nablus, Baghdad, and Damascus (1868) - were not borne out of an inherent

14 Donald Read, The Age of Urban Democracy, England, 1868-1914, rev. ed. (London: Longman, 1994).

15 Timothy Mitchell, Colonising Egypt (Cambridge: Cambridge University Press, 1988); Mary Poovey, Making a Social Body: British Cultural Formation, 1830-1864 (Chicago, University of Chicago Press, 1995); Patrick Joyce, The Rule of Freedom: Liberalism and the Modern City (London: Verso, 2003).

16 William Cohen, Urban Government and the Rise of the French City: Five Municipalities in the Nineteenth-Century (New York: St. Martin's Press, 1998), 21-58. For an overview of how municipalities dealt with the challenges of urbanization in the modern Middle East, see Vincent Lemire, "Urbanités, municipalités, citadinités," in Le Moyen-Orient fin XIXe-XXe siècle, ed. Leyla Dakhli (Paris: Seuil, 2016).

17 Benjamin, "Thesis VII," On the Concept of History. 
democratic impulse and were not conceived as mere replicas of European urban governance models. ${ }^{18}$ As in Europe, these institutions were set up in response to a mixture of immediate urban crises, particularly in public health, the structural transformation of - and economic rivalry between - cities, and the ascent and self-assertion of an Arabo-Ottoman merchant class against foreign rivals. What necessitated the appointment of a municipal council in Beirut was the precipitous influx of refugees in the wake of the civil war in Mount Lebanon and the Damascus massacres in the summer of $1860 .{ }^{19}$

The Tanzimat politicians in Istanbul had heralded municipal reform as a civilizational leap forward. ${ }^{20}$ In 1858 , they created the municipal authority of the Sixth District of Galata and Pera as a model not only for other districts but also for the cities and towns of the entire empire. ${ }^{21}$ The Ottoman provincial law of 1867 put cities on a new political footing: "Every town shall be counted as a municipality." ${ }^{22}$ Elections were supposed to be held every two years for half

18 William Cleveland, "The Municipal Council of Tunis, 1858-1870: A Study in Urban Institutional Change," International Journal of Middle East Studies 9, no. 1 (1978): 42, and Nora Lafi, "Les pouvoirs urbains à Tunis à la fin de l'époque ottomane," in Municipalités méditerranéennes: Les réformes urbaines ottomanes au miroir d'une histoire comparée (Moyen-Orient, Maghreb, Europe méridionale), ed. Nora Lafi (Berlin: Klaus Schwarz, 2005), 232; for Beirut, Jerusalem and Damascus, see, in the same volume, Jens Hanssen, "The Origins of the Municipal Council in Beirut (1860-1908);" Yasemin Avcı and Vincent Lemire, "De la modernité administrative à la modernisation urbaine: une réévaluation de la municipalité ottomane de Jérusalem (1867-1917);" and Stefan Weber, "Laménagement urbain entre régulations ottomanes, intérêts privés et participation politique: la municipalité de Damas à la fin de l'époque ottomane (1864-1918) 142, 95, 181, respectively; for Nablus, see Mahmoud Yazbak, "The Municipality of a Muslim Town: Nablus 1868-1914," Archiv Orientální 67 (1999): 341; for Baghdad, see National Archives of the UK (TNA), FO 195/803A, No. 25, August 26, 1868. See also Mahmoud Yazbak's chapter, "Comparing Ottoman Municipalities in Palestine: The Cases of Nablus, Haifa and Nazareth, 18641914," in this volume.

19 Jens Hanssen, Fin de Siècle Beirut: The Making of an Ottoman Provincial Capital (Oxford; New York: Oxford University Press, 2005), 116-25.

20 Official memorandum, dated March 1856. Reproduced in Osman Nuri Ergin, Mecelle-i Umur-u Belediye [Book of municipal affairs], vol. 1 (Istanbul: Arşak Garoyan Matbaası, 1922), 1377-79.

21 On the Tanzimat reforms as a series of test balloons, see Jens Hanssen, "Practices of Integration: Centre-Periphery Relations in the Ottoman Empire," in The Empire in the City: Arab Provincial Capitals in the late Ottoman Empire, ed. Jens Hanssen, Thomas Philipp, and Stefan Weber (Wurzburg: Ergon, 2002).

22 Quoted in İlber Ortayli, Tanzimattan Sonra Mahalli Idareler (1840-1878) [Local administrations after the Tanzimat] (Ankara: Sevinç Matbaası, 1974), 166. 
the council, although by some accounts, in Jerusalem the first free elections were not held until 1908. In Beirut, they were organized early on by an electoral college of reputable elders and rotated from district to district for up to two weeks. The successful candidates were often Arab merchants and intellectuals from long-established families, but unlike on the provincial councils, Muslim and Christian clergy were conspicuously absent. Moreover, in a confessionally mixed city such as Beirut, sectarian block-voting was nipped in the bud by the vigilant press. The fact that the first four mayors were Egyptian-born reminds us that, unlike in provincial capitals with a long history in Islamic empires, Beirut had only recently experienced urban growth and a rise in stature. ${ }^{23}$

Although municipal elections were public affairs, these new democratic practices hardly constituted universal suffrage, nor can we speak of mass participation before 1908. They were severely circumscribed by class, gender, and urban residence biases. Voters had to be male Ottoman citizens over twentyfive and affluent enough to file taxes in excess of fifty piasters a year. Candidates were required to be above thirty years of age and own urban property taxed at a minimum of $5^{0,000}$ piasters. ${ }^{24}$ Moreover, budgetary autonomy was often threatened by deficits, and interference from provincial governors could not always be prevented by the local media. From the imperial perspective, the implementation of municipal reforms by elected members contributed a great deal to Ottoman pacification and considerable prosperity in Arab provincial capitals, especially after the Ottoman reassertion of power over the Arab provinces had generated so much urban sectarian violence in Aleppo (1850), Nablus (1856), Jidda (1858) and, finally, in Dayr al-Qamar, Zahleh, Hasbayya and Damascus in the summer of 1860 .

It is no coincidence that the emergence of provincial municipalities occurred in the decade between the enactment of the Ottoman land code of 1858 , which "henceforth provided the reference point in all property matters" for the empire, and the citizenship law in 1869 , which tied rights and duties to birthplace and residency. ${ }^{25}$ These and other laws regulated the operations of

23 Hanssen, Fin de Siècle Beirut, chap. 5.

24 "Belediye Kanunu," see Ottoman State Archives (воА), Yildiz Esas Evraki, 37/302/47-112 (1877).

25 Huri Islamoğlu, "Politics of Administering Property: Law and Statistics in the NineteenthCentury Ottoman Empire," in Constituting Modernity: Private Property in the East and West, ed. Huri Islamoğlu (London: I. B. Tauris, 2004), 292; and Ariel Salzmann, "Citizens in Search for a State: The Limits of Political Participation in the Late Ottoman Empire," in Extending Citizenship, Reconfiguring States, ed. Michael Hanagan and Charles Tilly (Lanham: Rowman \& Littlefield, 1999), 45. 
late Ottoman governmentality in which, from the local perspective, municipal councils were sites of governmental accountability and sources of citizenship. If today access to Ottoman state archives provides a much-needed perspectival complement to European sources, and the "view from above" provincializes the "view from outside," we are still desperately short on the view from within municipal archives. In Beirut, whose archive was destroyed in a flood in 1983 , I could only reconstruct the inner workings of councils by reading the municipal sections in the press.

Once municipalities were fully functioning in the Arab provinces, Nahda newspapers hailed these new institutions as political panacea for overcoming sectarian strife and securing economic growth. After 1867, some intellectuals, among whom Cairene 'Abdallah Abu al-Sa'ud, the Beirutis Butrus and Salim alBustani (1819-83, 1848-84), and the Damascene Adib Ishaq (1856-84), began to discuss the meanings and applications of democracy (al-dimukratīyya), free$\operatorname{dom}(a l-h u r r \bar{y} y a)$, equality (al-musawāt), and voting rights (haqqal-intikhāb). These were concepts that were introduced to the Arabic political lexicon a generation earlier in the pages of the Arabic press. ${ }^{26}$ Still skeptical that "democracy had ever existed, or will ever rule except on paper" some ten years after the first Beirut municipal council elections, Bustani nevertheless reminded his readers that "in this day and age, we can say that democracy is rule based on elections governed by laws ... as for the [recent Ottoman] elections, they are expressions of public opinion [al-rayy al-'amm]."27

These and countless other interventions in political affairs by literary figures - al-Bustani sat on the municipal council for two years - demand from urban historians today to move beyond the politics of notables. Albert Hourani's influential paradigm has helped us enormously to challenge racist conceptions of a timeless Islamic city. Nevertheless, it conveyed the idea that cities in the Middle East were governed by communal factions until the end of colonial rule. Notable families often had multiple members on councils, ${ }^{28}$ but

26 'Abdallah Abu al-Sa'ud, Al-Dars al-tamm fi al-tarikh al-'amm [A complete lesson in general history] (Cairo, 1872); Salim al-Bustani, Iftitahat Majalla al-Jinan al-Bayrutiyya, 18701884, [Editorials of the Beirut journal al-Jinan, 1870-1884] 2 vols., ed. Y. Khuri (Beirut: Dar al-Hamra', 1990); Adib Ishaq, al-Kitabat al-siyyasiyya wa al-ijtima'iyya [Political and social writings], ed. N. 'Allush (Beirut: Dar al-Tali'a, 1978).

27 Butrus al-Bustani, Da'irat al-Ma'arif [The encyclopedia], vol. 8 (Beirut: Librairie du Liban, 1956), 233 .

28 For an example of the predominance of one family - the Çalabis - see for example, Baghdad Salname (1896/7), 219-22: elected members of the provincial council: 'Abd al-Qadir Pasha, Shakir al-Alusi, Ibrahim Zaybaq, Mutawalli Na'man, Menakhim Salih, Rizqallah 'Abbud; 1. Municipal circle: Mustafa Jamil (mayor), elected members: Mahmud 
the sparse evidence that exists from Beirut suggests that municipal coalitions coalesced across lines of kinship and sectarianism. Instead, economic interests (merchants versus landowners), educational background (Muslim, missionary, state schools), and professional affiliations played a role. But ultimately, councilors represented the interests of the quarters that elected them.

Although a revised municipal ordinance of 1877 stipulated that there was going to be one municipal circle per 40,000 inhabitants, this was rarely implemented. Beirut retained a single unified municipality until at least 1908 for a population that by then had topped 100,000. Ottoman yearbooks indicate that Damascus had four municipal councils in 1884/86, two in 1897 and three between 1905 and 1909 for a population that reached 250,000 in $1911 .{ }^{29}$ Baghdad's yearbooks for 1892/3, 1896/7, and 1900/01 consistently featured three municipal circles (da'ire) for a voting population that reached approximately 67,000 by $1896 .^{30}$

Imperial capitals and colonial cities generally tended to have a poorer record of municipal governance than provincial cities. In Istanbul, as in Cairo, municipal experiments were discredited by the colonial attitudes of the European diplomats, and councilors were appointed state officials. ${ }^{31}$ The democratic deficit in imperial and national capitals is well-established. Paris, for example, only began electing mayors in 1977, and the sense of the provinces teaching the Ottoman imperial government a lesson in democracy is well captured in the playfully arrogant exclamation in a 1877 parliamentary session by the Tripoli deputy, Niqula Nawfal: "We are from the provinces, we have been

Sayrit, 'Abd al-Fattah Effendi, Habib Ef., 'Abd al-Qadir Çalabi, Mutawalli Hasan, Hajji Khalil Çalabi; 2. Municipal Circle: Ahmad Bey al-Rubay'i (mayor), Sayyid 'Abd al-Razzaq Ef., Sayyid 'Abdallah Çalabi, Hajji 'Ali Çalabi, Mahmud Çalabi; 3. Circle: Hajji Amin Çalabi, Sayyid Musa Ef., Sayyid 'Abd al-Qadir Çalabi, 'Abdallah Dawud Ef., 'Abd al-Majid Çalabi, Yusuf Çalabi.

29 Stefan Weber, Damascus: Ottoman Modernity and Urban Transformation, 1808-1918, 2 vols. (Aarhus: Aarhus University Press, 2009), vol. 1, 37-38; vol. 2, 7. For urban populations, see also Ernest Weakley, Report upon the Conditions and Prospects of British Trade in Syria, Cd. 5707 (London: HMsO, 1911), 32.

30 On the problem of reading population statistics in Baghdad's Ottoman yearbooks, see Christoph Herzog, Osmanische Herrschaft und Modernisierung im Irak: Die Provinz Bagdad, 1817-1917 (Bamberg: University of Bamberg Press, 2012), 687-94.

31 Steven T. Rosenthal, The Politics of Dependency: Urban Reform in Istanbul (Westport: Greenwood Press, 1980). Alexandria's urban administration faced similar foreign interference. See Michael Reimer, "Urban Regulation and Planning Agencies in Mid-NineteenthCentury Alexandria and Istanbul," Turkish Studies Association Bulletin 19, no. 1 (1995). 
voting since the beginning of the Tanzimat. Istanbul, however, has encountered elections only this year." 32

These developments point to the need for a double historiographical revision at the intersection of urban and intellectual history. First, it was the rapid material transformation of cities, rather than the mimicry of grand European ideas of democracy, that led first to a profound legal and administrative recalibration. We can hypothesize that it was only then that there was more widespread critical discourse on the merits of the democratic process. Second, and with this hypothesis in mind, the foundational doomed-to-failure narratives by orientalist urban historians such as Gabriel Baer, or by political economists such as Stephen Rosenthal, have set the defeatist paradigm that still structures late Ottoman urban historiography. ${ }^{33}$ Relying largely on European sources, both shared the assumption that municipalities were Western, thus alien, constructs in the Middle East. On their authority, the Zionist historian Ruth Kark could claim that "this new [municipal] institution did not have its roots in the Muslim Middle East but rather influenced by European, and particular French, concepts." ${ }^{4}$

Such widespread views have inoculated urban research, especially on Palestine, against the municipal revolution that took place in the late nineteenth century. Instead, scholarship continued to deploy "folklorist ... religious, or patrimonial approaches" on outmoded and doomed-to-disappear urban heritage: guilds and suqs, timeless religious communities and their sacred places or the honeycombed features of domestic architecture and urban morphology. ${ }^{35}$ Research projects such as Nora Lafi's challenge this antimodern trend. Her project, which aims to trace urban government's structural continuity between pre-Tanzimat urban administration and late Ottoman municipalization, offers a useful counternarrative. On its own, however, this narrative also takes a "transformophobe" position. In effect, if not intent, it does not allow for the possibility that a complete overhaul of urban government was deemed desirable and necessary, not least because late Ottoman cities such as Beirut

32 Tarik Hakki Us, Meclis-i Me'busan Żabıt Ceridesi [The official gazette of the Chamber of Deputies] (Istanbul, 1939-1954), April 17, 1877 session, 84-85, taken from İlber Ortayli, Studies on Ottoman Transformation (Istanbul: Isis Press, 1994), 115. Nawfal came from a family of Nahdawis and was the official Arabic translator of Ottoman legal texts like the constitution of 1877. Hanssen, Fin de Siècle Beirut, 115.

33 Gabriel Baer, Studies in the Social History of Modern Egypt (Chicago: University of Chicago Press, 1969). See chapter "The Beginnings of Municipal Government," 190-209.

34 Ruth Kark, "The Jerusalem Municipality at the End of Ottoman Rule," Asian and African Studies 14, no. 2 (1981): 117.

Lemire, “Urbanités, municipalités, citadinités," 117. 
grew so much that only new political structures and procedures could possibly address real concerns about public health and safety, social welfare, and European financial and cultural encroachment. ${ }^{36}$ While criticism and protests against some of the effects of the Tanzimat were amply found, none of the alternative political ideas called for a return to a pre-Tanzimat Ottoman Empire.

In Fin de Siècle Beirut, I criticize the elite nature, reformist politics, and public morality discourse emanating from municipal politics in fin-de-siecle Beirut. In the book, I harbor disappointment at the lack of radical politics on and around municipal councils, compared to the Mediterranean anarchists whom Ilham Khouri-Makdisi resurrected for us, or compared to the municipal socialism that William Cohen spotted in France. ${ }^{37}$ Like elsewhere in the world, elections remained a privilege of the male elite until suffragettes fought for women's rights to vote in the interwar years. Yet, I could not dismiss the archival evidence of enormous public investment in the municipality, both on the pages of Beirut's biweekly newspapers, most of which had a section on baladiyyat - municipal news - and in highly contested election campaigns. Nor could I help noticing that municipal councils were by no means willing conduits for European finance capitalism. Rather, various European legal codes were adopted - at least in theory - to defend the city against European business interests. The most radical, if symbolic, act in this regard was the stipulation in the 1877 municipal reform law that foreign residents were henceforth barred from municipal councils.

After World War I, the age of urban democracy came to an end with the imposition of the mandate state system over the fluid provincial borders around the Syrian desert. ${ }^{38}$ Fearing that, like in European cities, municipalities would become dens of socialists, colonial regimes did not remove property

36 Lafi, Municipalités Méditerranéennes. More recently, Lafi adopts the fruitful paradigm of transnational municipalism and acknowledges the multidirectional forms of governance modeling simultaneously among Ottoman cities and between them and European and Asian municipalities. See "Mediterranean Connections: The Circulation of Municipal Knowledge and Practices during the Ottoman Reforms, c. 1830-1910," in Another Global City: Historical Explorations into the Transnational Municipal Moment, 1850-200o, ed. Pierre-Yves Saunier and Shane Ewen (New York: Palgrave Macmillan, 2008).

Ilham Khuri-Makdisi, The Eastern Mediterranean and the Making of Global Radicalism, 1860-1914 (Berkeley: University of California Press, 2010); Cohen, Urban Government, 21-58.

38 Salim Tamari, “The Great War and the Erasure of Palestine's Ottoman Past," in Transformed Landscapes: Essays on Palestine and the Middle East in Honor of Walid Khalidi, ed. Camille Mansour and Leila Fawaz (Cairo: American University in Cairo Press, 2009). On the 
requirements for election candidates. Gender discrimination and municipal elitism was consolidated and confessionalized. While Damascus, Beirut, Baghdad, Jerusalem, and Amman were favoured as colonial capitals, the rest of the Ottoman family of provincial capitals - Hama, Nablus, Aleppo, and Mosul, for example - suffered marginalization in the new national economies, as they were cut off from their historical trade routes by national borders and state centralization in the 1950s. Municipal councils continued to exist, but the mantra of national development reduced them to their technocratic functions. In the 196os, 70s, and 8os, decolonization's new authoritarian regimes applied the tabula-rasa principles of high modernism to the capitals of new independent nation-states. In the name of modernization, urban planning destroyed much of the historical urban tissue colonialism had left to decay. The remaining urban fabric in Syria is being demolished by Russian and Syrian air force bombardments before our eyes.

Before we conclude with the municipal history of Jerusalem, it bears acknowledging that in the 21st century, mayors of provincial and state capitals have begun to assert their authority against the pressures of national governments and capitalist dictates to privatize urban infrastructure and public services. ${ }^{39}$ Recently in Beirut, the formidable municipal election campaign of the group Beirut Madinati, somewhat exuberantly hailed as the Lebanese Indignados, offered a vision of politics that, had it been elected, might have generated an democratic urban revolution out of the severe crises that the city faces. ${ }^{40}$ The fact that many cities in the Middle East are ravaged by war and others, like Beirut, are barely coping with their millions of refugees should encourage historians to do what we are best at in moments of contemporary dejection - to return to the past with renewed urgency.

\section{Jerusalem: Municipal History under Siege}

One of the most pernicious urban myths fabricated by colonialism, whether in the British, French, or Israeli variety, was its denial of the corporeal city. Despite all the above evidence of institutionalization in - and urban residents'

British suspension of municipal authorities in Iraq, see Charles Tripp, A History of Iraq (Cambridge: Cambridge University Press, 2007), 38.

39 The successful remunicipalizaton of water management in Paris in 2008 and Barcelona in 2013, for example, has energized the agency of municipalities in national and global politics.

Website of Beirut Madinati, accessed January 17, 2018, http://beirutmadinati.com. 
attachments to - Tanzimat cities that constitute urban corporeality, colonial canards about social fragmentation, religious and ethnic segregation, and lack of public spirit continue to haunt Zionist historiography and urban planners. I have showed elsewhere how the entanglements between urban sociology and orientalism renewed and perpetuated the Islamic city paradigm until the Algerian struggle for self-determination from 1954-62 offered critical historians a new perception of cities under colonial rule. ${ }^{41}$

Orientalist scholarship on the Islamic city worked hand in hand with heritage preservation and colonial aesthetics in North African cities. Hubert Lyautey, resident-general of Morocco from 1912-25, and a seasoned officer on the French imperial circuit, developed the dual-city - or, with Janet AbuLughod, urban-apartheid - approach. ${ }^{42}$ Lyautey used urban planning as a means to square European health and security concerns with the aesthetic appeal of Muslim architecture:

Touch the indigenous city as little as possible. Instead, improve their surroundings where, on the vast terrain that is still free, the European city rises, following a plan which realized the most modern conceptions of large boulevards, water and electrical supplies, squares and gardens, buses and tramways, and also foresee future expansion..$^{43}$

The Algerian War of Independence turned back the colonial gaze and exposed the ways in which colonial knowledge and power reinforced each other to perpetuate European domination. Studies on the nature of the Islamic city were replaced by studies on the colonial production of this category. The works of Fanon in Algeria, in particular, have highlighted how socio-economic and racial difference acquired physical form in a bifurcated dual city:

41 The Islamic city paradigm owed its longevity to a curious isnad, or chain of authorization: in the early 196os, the Chicago School of Urban Research collaborated with Gustave von Grunebaum, who had incorporated Max Weber's urban sociology into his orientalism. Weber had used Snouck Hurgronje's book on Mecca (1888) to compare "Occidental” and "Oriental" urban essences. For more details on this scholarly genealogy, see Jens Hanssen, "History, Heritage and Modernity: Cities in the Muslim World Between Destruction and Reconstruction," in The New Cambridge History of Islam, vol. 6, ed. Robert Hefner (Cambridge: Cambridge University Press, 2010).

42 Janet Abu-Lughod, Rabat: Urban Apartheid in Morocco (Princeton: Princeton University Press, 1980).

43 Lyautey quoted in Gwendolyn Wright, The Politics of Design in French Colonial Urbanism (Chicago: University of Chicago Press, 1991), 79. 
The settlers' town is strongly built, all made of stone and steel. It is a brightly-lit town; the streets are covered with asphalt ... [It] is not the prolongation of the native city. The colonizers have not settled in the midst of the natives. They have surrounded the native city; they have laid siege to it ... The native town is a crouching village, a town on its knees, a town wallowing in the mire. ${ }^{44}$

Since Fanon's "cri du casbah," a host of scholars have deconstructed the epistemological foundations of colonial violence in North Africa along with scholars' and architects' complicity in it. Urban underdevelopment in Algiers and elsewhere is not due to the pathology of a religion or civilization, as Gustave von Grunebaum asserted, but is rather a consequence of colonialism. Even though 'Abdallah Laroui rightly cautions against the romantic understanding of Algiers' history in Fanon's anticolonial manifestos, ${ }^{45}$ The Wretched of the Earth and $A$ Dying Colonialism have opened a space for charting an analytical shift in urban studies more generally. On the one hand, Muslim cities are conceived as sites of larger political, economic, and cultural transformations - colonialism, capitalism, nation-building, and modernity - in the Middle East. On the other, the experiences of urban dwellers are taken to hold the key to measuring the effects of these transformations.

If decolonization and Arab socialism failed to resurrect the late Ottoman municipal experiment in the second half of the twentieth century, it is perhaps understandable: the governments of newly independent states were worried about national unity and state sovereignty after decades of colonial rule and were optimistic about the potential of rapid, state-led development and welfare. The urgency of the municipal question has not receded in the current global moment of urbicide, however. Nowhere is this question more urgent than in the history of modern Arab Jerusalem. Jerusalem and the Palestinian territories it is supposed to serve as a national capital never had the luxury of a postindependence moment. Palestine still lives in a settler colonial present. ${ }^{46}$

44 Fanon, The Wretched of the Earth, 30; and Frantz Fanon, A Dying Colonialism, trans. Haakon Chevallier (1959, repr., New York: Grove Press, 1967), 51.

45 'Abdallah Laroui, L'idéologie arabe contemporaine: essai critique (Paris: François Maspéro, 1967), 5 .

46 For an astute analysis of the admixture of Israeli settler colonialism and colonialism, see Lorenzo Veracini, "The Other Shift: Settler Colonialism, Israel, and the Occupation," Journal of Palestine Studies 42, no. 2 (2013): 28: "The difference is absolutely critical: while a colonial society is successful only if the separation between colonizer and colonized is retained, a settler colonial project is ultimately successful only when it extinguishes 
Despite a Fanon-inspired paradigm shift in Middle East studies, in recent years, a variant of the dual cities approach has entered the field: the divided city. ${ }^{47}$ Research questions about governing diversity and overcoming sectarian geographies may apply to places like Berlin, Beirut, or Belfast. But to speak of a divided city in Jerusalem, beyond stating the obvious, potentially obfuscates the colonial structure of the dual city. For the academic study of Palestinian cities under occupation in general, Jerusalem and its historical port of Jaffa in particular have been key elements in the Zionist narrative appropriation of Palestinian land. ${ }^{48}$ Zionist historiography cast Palestinian cities as a fragmented patchwork of religious and ethnic communities, devoid of any urban spirit of public welfare. This view, which is steeped in Weberian modernization theory, set the historical stage for foreign intervention and Ashkenazi settlers. ${ }^{49}$

itself - that is when the settlers cease to be defined as such and become 'natives,' and their position becomes normalized."

47 For example, Jon Calame and Esther Charlesworth, Divided Cities: Belfast, Beirut, Jerusalem, Mostar and Nicosia (Philadelphia: University of Pennsylvania Press, 2009).

48 Alexander Schölch, Palästina im Umbruch, 1856-1882: Untersuchungen zur wirtschaftlichen und sozio-politischen Entwicklung (Stuttgart: Franz Steiner, 1986); Jakob Eisler, Der deutsche Beitrag zum Aufstieg Jaffas, 1850-1914: Zur Geschichte Palästinas im 19. Jahrhundert (Wiesbaden: Harrassowitz, 1997); Muhammad Tarawina, Qada Yafa fi al-'ahd al-'uthmani: dirasa idariyya iqtisadiyya ijtima'iyya, 1281-1333 h/1864-1914m [The district of Jaffa in the Ottoman period: administrative, economic and social studies, AH 1281-1333/ M 1864-1914] (Amman: Jordan Ministry of Culture, 200o); Tahir Adib al-Qalyubi, 'A'ilat wa shakhsiyyat min Yafa wa qada'iha [Families and personalities from Jaffa and its district] (Beirut: al-Mu'assasa al-'Arabiyya, 2006); Salim Tamari, Mountain Against the Sea: Essays in Palestinian Society and Culture (Berkeley: University of California Press, 2009); Anthony Travis, On Chariots with Horses of Fire and Iron: The Excursionists and the Narrow Gauge Railroad from Jaffa to Jerusalem (Jerusalem: Benjamin Shapell Family Manuscript Foundation; The Hebrew University Magnes Press, 2009); Johann Büssow, Hamidian Palestine: Politics and Society in the District of Jerusalem, 1872-1908 (Leiden: Brill, 2011); Yuval Ben-Bassat and Eyal Ginio, Late Ottoman Palestine: the Period of Young Turk Rule (London: I. B. Tauris, 2011); Farid al-Salim, Palestine and the Decline of the Ottoman Empire: Modernization and the Path to Palestinian Statehood (London: I. B. Tauris, 2015), and many others have done important reconstructive work.

49 See, for example, Ruth Kark, "The Traditional Middle Eastern City: The Cases of Jerusalem and Jaffa During the Nineteenth Century," Zeitschrift des Deutschen Palästina Vereins 97, no. 1 (1981). Recent colonial discourse analyses have offered powerful critiques of such orientalist constructions. See Mark Levine, Overthrowing Geography; Jaffa, Tel Aviv, and the Struggle for Palestine, 1880-1948 (Berkeley: University of California Press, 2005) and Michelle U. Campos, Ottoman Brothers: Muslims, Christians, and Jews in Early TwentiethCentury Palestine (Stanford: Stanford University Press, 2010). However, their uncritical 
Even the urban architecture that has withstood willful and ongoing destruction since 1948 continues to serve as a display for Israel's extinction narrative of Palestinian cities. This form of heritage preservation has much in common with how the survival of the old walled cities of Aleppo, Damascus, Algiers, or Fez into the twentieth century reassured the French public of the success of their government's civilizing missions. While Israeli civilian agencies have demolished Palestinian homes in and around Jerusalem and Jaffa at an accelerating pace, the preservation of some old, urban nuclei provides the new Israeli cities and "clean" settlements with affective claims to technological progress and cultural supremacy. ${ }^{50}$

Arab Jerusalem has been without a municipality since Israel conquered it in $1967 .{ }^{51}$ This has made it possible for Israeli mayors of West Jerusalem, particularly Teddy Kollek (in office 1967-93) to de-Arabize East Jerusalem in the name of biculturalism. ${ }^{52}$ In the two decades before Israeli annexation, Jordanian authorities were busy refashioning the Hashemite king as the protector of the Holy Sites, upgrading Jerusalem and incorporating it into the kingdom. ${ }^{53}$ Meanwhile, the municipality of Arab Jerusalem fought the Hashemites' neglect and betrayal of other parts of the city, particularly Shaykh Jarrah and Silwan. ${ }^{54}$

adoption of the colonial/national telos has continued to isolate Palestine from wider late Ottoman intersections.

Adnan Abdelrazik and Khalil Tofakji, Israeli Colonial Policies and Practices:De-Arabization of East Jerusalem (Jerusalem: Arab Studies Society, 2008); David Hughes, Nathan Derejko and Alaa Mahajna, Dispossession and Eviction in Jerusalem: The Cases and Stories of Sheikh Jarrah (Jerusalem: Civic Coalition for Defending the Palestinians, 2009).

$5^{1} \quad$ Walid Khalidi, "Israel's 1967 Annexation of Arab Jerusalem: Walid Khalidi's Address to the UN General Assembly Special Emergency Session, 14 July 1967," in Journal of Palestine Studies 42, no. 1 (2012); Thomas Abowd, Colonial Jerusalem: The Spatial Construction of Identity and Difference in a City of Myth, 1948-2012 (Syracuse: Syracuse University Press, 2014); Usama Halabi, Baladiya al-Quds al-'arabi [The municipality of Arab Jerusalem] (Jerusalem: Passia, 1993).

52 Oscar Jarzmik, "Theodore 'Teddy' Kollek, the Palestinians, and the Organizing Principles of Israeli Municipal Policy, 1967-1987" (PhD diss., Toronto University, 2016).

53 Kimberly Katz, Jordanian Jerusalem: Holy Places and National Spaces (Gainesville: University Press of Florida, 2005).

54 Daniel Rubenstein, "The Jerusalem Municipality under the Ottomans, British, and Jordanians," in Jerusalem: Problems and Prospects, ed. Joel Kraemer (New York: Praeger, 1980). 
The British employed similar strategies of the symbolic upgrading and systematic demunicipalization of Ottoman Jerusalem. ${ }^{55}$ Before the Mandate period, the northern districts of Palestine had been under the administration of the province of Beirut. In 1918, they were placed under the jurisdiction of Jerusalem, which became the de facto capital of Palestine. British officials quickly replaced municipal electoral processes with government appointments, reduced the council's Muslim membership, and added ten British bureaucrats to establish a sectarian quota whose structure remained in place until $1948 .{ }^{56}$ While other British mandates in the region established parliaments and cabinets, colonial authorities factionalized Palestinian politics by granting newly invented institutions, such as the position of mufti, as family fiefdoms. With the increase of Zionist settlers in the city, the British divided Jerusalem into a dozen electoral wards in 1934, but it was only in the Fitzgerald Plan of 1945 that Jerusalem was bifurcated into a Jewish West and an Arab East. $^{57}$

Compared diachronically to these and many other British policies of political de-development and demunicipalization, the late Ottoman municipality of Jerusalem appears like a time and a place for urban democracy, even under the autocratic rule of Sultan 'Abdülhamid II. However, compared synchronically to other late Ottoman municipalities such as Nablus and especially Beirut, Jerusalem was a slow starter. The reason for this seems to lie less in its smaller size or remote location than in the same factors that stifled the democratic experiments of Istanbul, Alexandria, and Cairo: European diplomatic and religious interests. But it may also be that we simply do not know enough about the inner workings of the municipality of late Ottoman Jerusalem. ${ }^{58}$ We know

55 See Falestin Naïli, "La dé-municipalisation de la gouvernance urbaine et de l'espace politique post-ottoman: le cas de Jérusalem," Les carnets de l'Ifpo, February 7, 2017, accessed January 17, 2018, http://ifpo.hypotheses.org/7428.

56 Mu’tasem Hasan Ahmed Naser, “Jerusalem Municipality and Political Conflict: 1918-1942," International Journal of History and Philosophical Research 4, no. 1 (2016).

57 Michael Dumper, The Politics of Jerusalem Since 1967 (New York: Columbia University Press, 1997), 27.

$5^{8}$ Recent work in Arabic, Turkish and French has begun to change this. Mahmud Nahar al-Shannaq, Baladiyyat al-Quds al-shariffi al-'ahd al-'uthmani: dirasat [The municipality of Jerusalem in the Ottoman period: studies] (Ramallah: Filastin: Wizarat al-Ilam, 2010); Yasemin Avcı, Degişim sürecinde bir Osmanlı kenti: Kudüs (189o-1914) [An Ottoman city in the period of transformation:Jerusalem, 1890-1914] (Ankara: Phoenix, 2004), and Vincent Lemire, La soif de Jérusalem: essai d'hydrohistoire (1840-1948) (Paris: Publications de la Sorbonne, 2010). 
that of the sixteen Jerusalem mayors between 1863 and 1910, only four were not from the Khalidi, 'Alami, and Husayni families. ${ }^{59}$ We still have very little information about the composition of Jerusalem's municipal council. In this light, the work of the Open Jerusalem team on the recently discovered minutes of the municipal council meetings is promising, not just for Jerusalem but also for other municipalities, where no such documents have been found. ${ }^{60}$ It may just carry forward the "weak messianic power" of late Ottoman democracy.

59 Büssow, Hamidian Palestine, 554-55.

6o Yasemin Avcı, Vincent Lemire and Falestin Naili, "Publishing Jerusalem's Ottoman Municipal Archives (1892-1917)," Jerusalem Quarterly, no. 60 (2014). 